\title{
IMPLEMENTASI SURAT PERJANJIAN MENURUT HUKUM PERDATA DAN KEBIASAAN MASYARAKAT ADAT SETEMPAT
}

\author{
Imman Yusuf Sitinjak ${ }^{1}$, Sariaman Gultom ${ }^{2}$, Christian Daniel Hermes ${ }^{3}$, Mariah SM Purba ${ }^{4}$ \\ ${ }^{1,2,3,4)}$ Program Studi PPKn, FKIP, Universitas Simalungun \\ e-mail: immanjoes@gmail.com¹,sariamangultom1966@gmail.com²,chrisdhermes@gmail.com³ \\ mariapurba132019@gmail.com ${ }^{4}$
}

\begin{abstract}
Abstrak
Dilaksanakan pengabdian masyarakat ini adalah untuk memberikan pemahaman, mengevaluasi masalah didalam masyarakat serta mengupayakan memberikan solusi terhadap masalah yang ada di masyarakat terutama mengenai perjanjian di Desa Tamba Kecamatan Sitiotio Kabupaten Samosir. Pelaksanaan gadai dimasyarakat adat samosir merupakan kebiasaan yang dilakukan oleh masyarakat sejak dulu. Kebanyakan yang objek dari gadai tersebut adalah tanah, khususnya tanah pertanian. Hal ini dilakukan oleh masyarakat adat samosir adalah untuk memenuhi kebutuhan mendesak mereka pada saat melakukan gadai seperti biaya pendidikan anak, kebutuhan ekonomi, dan kebutuhan yang lainnya yang dianggap penting. Masalah yang terjadi didesa tersebut adalah adanya perjanjian gadai dibawah tangan oleh masyarakat namun tidak selesai hingga berpuluh tahun lamanya. Dengan adanya pengabdian masyarakat ini dapat memberikan solusi terhadap masalah perjanjian tersebut. Sehingga pelaksanaan gadai yang dilakukan masyarakat adat memiliki penyelesaian.
\end{abstract}

Kata kunci: Perjanjian, Gadai, Masyarakat Adat

\begin{abstract}
This community service is carried out to provide understanding, problems in the community and strive to provide solutions to problems that exist in the community, especially regarding the agreement in Tamba village, Sitiotio sub-district, Samosir district. The implementation of pawning in the Samosir customary community is a habit that has been carried out by the community for a long time. Most of the objects of the pawn are land, especially agricultural land. This is done by the Samosir indigenous people to meet their closeness needs when making a pawn, such as the cost of children's education, economic needs, and other important needs. The problem that occurred in the village was the existence of a pawn agreement under the hands of the community but it was not completed for decades. With this community service, it can provide solutions to these problems. So that the implementation of pawning by indigenous peoples has a solution.
\end{abstract}

Keywords: Agreement, Pawn, Indigenous Peoples

\section{PENDAHULUAN}

Janji merupakan hal yang sudah biasa dilakukan dimasyarakat, dimana membuat janji dilakukan oleh hampir seluruh masyarakat baik tua maupun muda baik secara lisan maupun tulisan. Banyak masyarakat yang tidak memahami apa itu janji namun melaksanakannya, dan bagaimana sebenarnya fungsi janji itu yang tertuang didalam sebuah tulisan.

Dalam Kamus Besar Bahasa Indonesia, perjanjian adalah "persetujuan tertulis atau dengan lisan yang dibuat oleh dua pihak atau lebih, masing-masing bersepakat akan mentaati apa yang tersebut dalam persetujuan itu." Menurut Pasal 1313 KUH Perdata, "Suatu persetujuan adalah suatu perbuatan dengan mana satu orang atau lebih mengikatkan dirinya terhadap satu orang atau lebih".

Didalam membuat perjanjian secara tulisan perlunya memahami bagaimana aturan didalam membuat perjanjian. 
Di dalam suatu perjanjian pada umumnya memuat beberapa unsur yaitu:

a. Pihak-pihak, paling sedikit ada dua orang. Para pihak yang bertindak sebagai subyek perjanjian, dapat terdiri dari orang atau badan hukum. Dalam hal yang menjadi pihak adalah orang, harus telah dewasa dan cakap untuk melakukan hubungan hukum. Jika yang membuat perjanjian adalah suatu badan hukum, maka badan hukum tersebut harus memenuhi syarat-syarat badan hukum yang antara lain adanya harta kekayaan yang terpisah, mempunyai tujuan tertentu, mempunyai kepentingan sendiri, ada organisasi;

b. Persetujuan antara para pihak, sebelum membuat suatu perjanjian atau dalam membuat suatu perjanjian, para pihak memiliki kebebasan untuk mengadakan tawar-menawar diantara mereka;

c. Adanya tujuan yang akan dicapai, baik yang dilakukan sendiri maupun oleh pihak lain, selaku subyek dalam perjanjian tersebut. Dalam mencapai tujuannya, para pihak terikat dengan ketentuan bahwa tujuan tersebut tidak boleh bertentangan dengan undang-undang, kesusilaan dan ketertiban umum;

d. Ada prestasi yang harus dilaksanakan, para pihak dalam suatu perjanjian mempunyai hak dan kewajiban tertentu, yang satu dengan yang lainnya saling berlawanan. Apabila pihak yang satu berkewajiban untuk memenuhi prestasi, bagi pihak lain hal tersebut merupakan hak, dan sebaliknya;

e. Ada bentuk tertentu, suatu perjanjian dapat dibuat secara lisan maupun tertulis. Dalam hal suatu perjanjian yang dibuat secara tertulis, dibuat sesuai dengan ketentuan yang ada;

f. Syarat-syarat tertentu, dalam suatu perjanjian, isinya harus ada syarat-syarat tertentu, karena suatu perjanjian yang sah, mengikat sebagai Undang-Undang bagi mereka yang membuatnya. Agar suatu perjanjian dapat dikatakan sebagai suatu perjanjian yang sah, perjanjian tersebut telah memenuhi syarat-syarat tertentu. Agar suatu perjanjian dapat menjadi sah dan mengikat para pihak, perjanjian harus memenuhi syarat-syarat sebagaimana yang ditetapkan dalam Pasal 1320 KUHPerdata yaitu:

1) Sepakat mereka yang mengikatkan dirinya; Sepakat mereka yang mengikatkan dirinya mempunyai arti bahwa para pihak yang membuat perjanjian telah sepakat atau salingmenyetujui kehendak masing-masing, yang dilahirkan oleh para pihak tanpa adanya paksaan, kekeliruan, dan penipuan. Kata "sepakat" tidak boleh disebabkan adanya kekhilafan mengenai hakekat barang yang menjadi pokok persetujuan atau kekhilafan mengenai diri pihak lawannya dalam persetujuan yang dibuat terutama mengingat dirinya orang tersebut; Sepakat sebenarnya merupakan pertemuan antara dua kehendak, di mana kehendak orang yang satu saling mengisi dengan apa yang dikehendaki pihak lain. Menurut Teori Penawaran dan Penerimaan (offer and acceptance), bahwa pada prinsipnya suatu kesepakatan kehendak baru terjadi setelah adanya penawaran (offer)dari salah satu pihak dan dikuti dengan penerimaan tawaran (acceptance) oleh pihak lain dalam kontrak tersebut.

2) Cakap untuk membuat perikatan; Membuat suatu perjanjian adalah melakukan suatu hubungan hukum. Yang dapat melakukan suatu hubungan hukum adalah pendukung hak dan kewajiban, baik orang atau badan hukum, yang harus memenuhi syarat-syarat tertentu.

3) Suatu hal tertentu; Sebagai syarat ketiga disebutkan bahwa suatu perjanjian harus mengenai suatu hal tertentu, artinya apa yang diperjanjikan hak-hak dan kewajiban kedua belah pihak jika timbul suatu perselisihan. Barang yang dimaksudkan dalam perjanjian paling sedikit harus ditentukan jenisnya. Bahwa barang itu sudah ada atau sudah berada di tangannya si berutang pada waktu perjanjian dibuat, tidak diharuskan oleh Undang-Undang. Juga jumlahnya tidak perlu disebutkan, asal saja kemudian dapat dihitung atau ditetapkan. Perjanjian harus menentukan jenis objek yang diperjanjikan. Jika tidak, maka perjanjian itu batal demi hukum. Pasal 1332 KUHPerdata menentukan hanya barangbarangyang dapat diperdagangkan yang dapat menjadi obyek perjanjian, dan berdasarkan Pasal 1334 KUHP Perdata barang-barang yang baru akan ada 
dikemudian hari dapat menjadi obyek perjanjian kecuali jika dilarang oleh Undang-Undang secara tegas.

4) Suatu sebab atau causa yang halal; Menurut Undang-Undang, sebab yang halal adalah jika tidak dilarang oleh Undang-Undang, kesusilaan dan ketertiban umum, ketentuan ini disebutkan pada Pasal 1337 KUHPerdata. Suatu perjanjian yang dibuat dengan sebab atau causa yang tidak halal, misalnya jual beli ganja, untuk mengacaukan ketertiban umum.

Melalui pendidikan tentang perjanjian diharapkan masyarakat lebih memahami kedepannya tentang surat perjanjian tertulis, baik secara hukum maupun yang sedang berlaku didalam masyarakat setempat.

Dilaksanakan pengabdian masyarakat ini adalah untuk memberikan pemahaman, mengevaluasi masalah didalam masyarakat serta mengupayakan memberikan solusi terhadap masalah yang ada di masyarakat terutama mengenai perjanjian di desa tamba kecamatan sitiotio kabupaten Samosir.

Adapun tujuan dari Pengabdian masyarakat melalui ceramah adalah: (1) Dilaksanakan demi memberikan keilmuan penceramah tentang perjanjian dimasyarakat. (2) dari keilmuan pemberi ceramah untuk dapat diaplikasikan kepada masyarakat baik secara teoritis dan praktisi; dan (3) Dapat menumbuhkan pemahaman masyarakat tentang pentingnya mengerti dalam pembuatan perjanjian.

Dengan demikian, diharapakan kepada masyarakat setempat agar nantinya dapat mengerti tentang keberadaan perjanjian di dalam masyarakat. Demikian juga tanggungjawab pihak Universitas dalam hal ini Program Studi Pendidikan PPKn FKIP-USI untuk terus membina dan menunjang masyarakat setempat agar lebih berminat dan tertarik serta turut berpatisipasi berbagi dilema perjanjian yang berlaku dimasyarakat setempat..

\section{METODE}

Adapun metode yang digunakan dalam pelaksanaan kegiatan kemitraan ini adalah metode penyuluhan yang mana pelaksanaannya sebagai berikut:

1. Pertama, tim pengusul melakukan survey ke lapangan dan melihat kondisi serta permasalahan yang dihadapi oleh mitra. Dalam tahap ini Tim akan mempersiapkan 2 hal, yaitu: (1) Penyiapan petugas; petugas ini akan melibatkan dosen prodi, (2) Penyiapan lapangan; melakukan konfirmasi dengan mitra.

2. Tahap Pengkajian

Tahap ini sangat penting yang mencakup identifikasi potensi dan masalah yang terjadi dengan Mitra. Kegiatan assessment meliputi pengumpulan dan analisis informasi, serta memadukan berbagai fakta yang ada sehingga memberikan suatu pemahaman. Dalam tahap ini mitra aktif dalam mengemukakan permasalahan dan kendala yang dihadapi. Proses pelaksanaan assessment tersebut secara tidak langsung sudah dilakukan sebagai kegiatan intervensi terhadap masyarakat, yaitu memberikan penyadaran akan pentingnya pengetahuan tentang perjanjian.

3. Tahap Perencanaan Alternatif Program

Tim secara aktif melibatkan mitra untuk memberikan solusi atas permasalah yang terjadi. Solusi-solusi diatas ditetapkan untuk diimplementasikan kepada mitra. Pertama, memaparkan secara garis besar materi. Kedua, melaksanakan kegiatan pelatihan bagi masyarakat. Dan ketiga, melakukan pendampingan bagi masyarakat dalam menerapkan pembuatan perjanjian. Pelatihan ini dihadiri kurang lebih 20 mitra. Dengan terlaksananya kegiatan tersebut diharapkan dapat meningkatkan pengetahuan masyarakat.

4. Tahap Pemformulasian Rencana Aksi

Tim menetapkan rencana yang akan dilakukan dan membantu mitra untuk melakukan kegiatan-kegiatan serta pendampingan kepada masyarakat. Masyarakat sebagai mitra dapat mengembangkan potensi diri dan meningkatkan pengetahuan yang di paparkan di masyakakat. Maka kerjasama yang baik antara tim, kelompok mitra, dan mahasiswa harus terjalin. Keterlibatan mitra dalam kegiatan ini merupakan kunci sukses dalam pelaksanaan PKM.

5. Tahap Evaluasi

Evaluasi senantiasa dilakukan tim atas kegiatan yang dilakukan dengan melibatkan mitra. 
Tahap evaluasi dilakukan tim mulai dari tahap persiapan sampai dengan pelaksanaan.

Program ini mendapat respon yang baik dari kelompok mitra yang terlibat dalam kegiatan pengabdian masyarakat. Dengan adanya kegiatan tersebut, akan menambah wawasan masyarakat dan meningkatkan kualitas serta inovasi dimasyarakat sehingga kualitas dimasyarakat semakin meningkat. masyarakat juga mengharapkan kegiatan ini terus berkesinambungan sehingga ilmu dan wawasan mereka terus bertambah.

\section{HASIL DAN PEMBAHASAN}

Hasil pelaksanaan pengabdian masyarakat di desa tamba kecamatan sitiotio Kabupaten Samosir mendapatkan hasil bahwa banyak masyarakat adat setempat yang masih melakukan gadai tanah. Bukan hanya itu saja gadai tanah tersebut juga banyak yang merupakan gadai yang dibuat dibawah tahun 1990 atau telah berumur puluhan tahun dan dianggap masih berlaku sampai saat ini sekalipun pelaku gadai tersebut telah meninggal.

Gadai pada umum nya memliki tenggat waktu yang tertuang didalam perjanjian gadai nya. Bagi masyarakat setempat gadai tidak harus kepada pihak Bank ataupun lembaga keuangan non bank lainnya. Asalkan para pihak pelaku gadai mau sama mau dan sepakat maka gadai yang dibuat oleh masyarakat adat didesa tersebut sah dan berlaku bagi mereka.

Menurut Pasal 1150 KUHPerdata, gadai merupakan suatu hak yang diperoleh berpiutang atas suatu benda bergerak, yang diserahkan kepadanya oleh seorang berutang atau orang lain atas namanya, dan yang memberikan kekuasaan kepada si berpiutang itu untuk mengambil pelunasan dari barang tersebut secara didahulukan dari orang-orang berpiutang lainnya, kecuali haruslah didahulukan biaya untuk melelang barang serta biaya yang telah dikeluarkan untuk menyelamatkan barang yang digadaikan tersebut.

Salim HS sendiri menyatakan bahwa yang dimaksud dengan gadai adalah suatu perjanjian yang dibuat antara kreditur dengan debitur di mana debitur menyerahkan benda bergerak kepada kreditur untuk menjamin pelunasan suatu hutang gadai, ketika debitur lalai melaksanakan prestasinya. Menurut nya gadai dikonstruksikan sebagai perjanjian accesoir (tambahan), sedangkan perjanjian pokoknya adalah perjanjian pinjam meminjam uang dengan jaminan benda bergerak. Apabila debitur lalai dalam melaksanakan kewajibannya, barang yang telah dijaminkan oleh debitur kepada kreditur dapat dilakukan pelelangan untuk melunasi hutang debitur.

Dari pendapat diatas dapat disimpulkan bahwa penerima gadai diberikan kuasa oleh pemberi gadai untuk mengambil atau mendapatkan hutang gadai dari pemberi gadai untuk melunaskan hutang pemberi gadai tersebut sebagai jaminan merupakan perjanjian gadai dan barang yang digadai. Dengan kata lain untuk menjamin pemberi gadai untuk melunaskan hutangnya pada penerima gadai.

Yang menjadi pokok permasalahan dari pelaksanaan gadai tersebut diatas adalah para penerima gadai tidak dapat menggadaikan kembali gadai nya kepada orang lain ketika mereka membutuhkan uang, serta para penerima gadai juga hanya dapat menunggu kapan gadai tersebut dilunasi oleh pemberi gadai. Ketika pemberi gadai telah meninggal bukan berarti gadai tersebut dianggap telah lunas atau gadai dianggap hapus, malahan gadai tersebut diwariskan kepada keturunan pemberi gadai. Didalam perjanjian gadai lama yang dibuat terdapat masa waktu berlaku selesai gadai tersebut, namun sampai lewat waktu gadai masih saja berlaku. Yang paling bermasalahnya adalah ketika surat gadai itu hilang ditangan penerima gadai maka gadai tersebut dianggap tidak berlaku lagi.

Maka dari pada itu melalui pengabdian masyarakat ini didapat solusi penyelesaian dengan cara pembaharuan dari perjanjian gadai tersebut. Melalui pembaharuan surat perjanjian gadai tersebut, maka gadai tersebut tidak lagi dalam keadaan daluwarsa waktu dalam perjanjian serta pertanggungjawaban untuk melunaskan gadai jelas diterima oleh siapa dan dapat diatur bagaimana cara pelunasan hutang tersebut selanjutnya.

Pembaharuan perjanjian gadai dibuat sebagai inovasi dan perkembangan pembuatan perjanjian bidang keilmuan yang mana dapat memberikan solusi kepada mereka yang merasa tidak puas maupun merasa kesulitan untuk mengambil kembali hutang gadai mereka. 


\section{SIMPULAN}

Hasil pelaksanaan pengabdian masyarakat bahwa banyak masyarakat adat setempat yang masih melakukan gadai tanah. Bukan hanya itu saja gadai tanah tersebut juga banyak yang merupakan gadai yang dibuat dibawah tahun 1990 atau telah berumur puluhan tahun dan dianggap masih berlaku sampai saat ini sekalipun pelaku gadai tersebut telah meninggal. Solusi penyelesaian dengan cara pembaharuan dari perjanjian gadai tersebut. Melalui pembaharuan surat perjanjian gadai tersebut, maka gadai tersebut tidak lagi dalam keadaan daluwarsa waktu dalam perjanjian serta pertanggungjawaban untuk melunaskan gadai jelas diterima oleh siapa dan dapat diatur bagaimana cara pelunasan hutang tersebut selanjutnya. Pembaharuan perjanjian gadai dibuat sebagai inovasi dan perkembangan pembuatan perjanjian bidang keilmuan yang mana dapat memberikan solusi kepada mereka yang merasa tidak puas maupun merasa kesulitan untuk mengambil kembali hutang gadai mereka.

\section{SARAN}

Sebaiknya masyarakat lebih terbuka untuk menyelesaikan masalah gadai yang ada dimasyarakat adat desa tamba kabupaten Samosir. Dan bagi peneliti dan pelaksana pengabdian masyarakat selanjutnya dapat meneliti masalah masalah yang masih ada dalam perjanjian gadai tersebut.

\section{UCAPAN TERIMA KASIH}

Penulis mengucapkan terima kasih kepada kantor desa dan karang taruna desa tamba kecamatan sitiotio kabupaten Samosir atas bantuan dan kerjasama yang baik dalam mensukseskan kegiatan pengabdian masyarakat oleh prodi PPKn FKIP Universitas Simalungun.

\section{DAFTAR PUSTAKA}

Departemen Pendidikan Nasional, 2005, Kamus Besar Ikthasar Indonesi Edisi Ketiga, Balai Pustaka, Jakarta

Sudarsono, 2007, Kamus Hukum, Rineka Cipta, Jakarta

Syamsuddin. Mohd. Syaufii, 2005, Perjanjian-Perjanjian dalam Hubungan Industrial, Sarana Bhakti Persada, Jakarta

Syahrani. Ridhuan, 1992, Seluk-Beluk dan Asas-Asas Hukum Perdata, Alumni, Bandung

Satrio. J, 2001, Hukum Perikatan, Perikatan Yang Lahir Dari Perjanjian, Buku I, Citra Aditya Bakti, Bandung

Kitab Undang-Undang Hukum Perdata (Burgerlijk Wetboek), 2008, diterjemahkan oleh Subekti dan Tjitrosudibio, Cet. 39, Pradnya Paramita, Jakarta

Salim HS, 2007, Perkembangan Hukum Jaminan di Indonesia, Ed. 1, PT Raja Grafindo Persada, Jakarta 